\title{
TECHNIQUES USED FOR ANALYSIS OF METALS AND ORGANIC COMPOUNDS IN WASTEWATERS, GRAYWATER AND RAINWATER: A BRIEF REVIEW
}

\author{
Vinícius Silva dos Santos ${ }^{a}$, Lilian Lefol Nani Guarieiro ${ }^{a}$ \\ a SENAI CIMATEC - Centro Integrado de Manufatura e Tecnologia, 41650-010, \\ Salvador-BA, Brasil
}

\begin{abstract}
Water recycling is a sustainable way of managing water resources in view of the large consumption of fresh water in the world caused by population growth, urbanization and industrial development. However, the reuse of fresh water requires great care due to the appearance of contaminants after its use, such as active chemicals, micropollutants and pharmaceutical products. Bearing in mind the importance of characterizing these waters in view, this work presents a systematic review of articles where techniques were used to evaluate metals and organic compounds in wastewater samples, which is nothing more than a combination of effluents, in addition to graywater originated from bathrooms, showers, and kitchen sinks, and rainwater between the years 2000 and 2020.
\end{abstract}

Keywords: systematic review; characterization; wastewater; graywater; rainwater.

\section{TÉCNICAS EMPREGADAS PARA A ANÁLISE DE METAIS E COMPOSTOS ORGÂNICOS EM ÁGUAS RESIDUÁRIAS, ÁGUAS CINZAS E ÁGUAS PLUVIAIS: UMA BREVE REVISÃO}

Resumo: A reciclagem das águas é uma forma sustentável de gerenciar os recursos hídricos tendo em vista o grande consumo de água doce no mundo ocasionado pelo crescimento populacional, a urbanização e o desenvolvimento industrial. No entanto a reutilização das águas doce requer muito cuidado devido o surgimento de contaminantes após seu uso, como produtos químicos ativos, micropoluentes e produtos farmacêuticos. Tendo a importância da caracterização dessas águas em vista, este trabalho apresenta uma revisão sistemática sobre artigos onde foram empregadas técnicas para avaliar metais e compostos orgânicos em amostras de águas residuárias que nada mais é do que uma combinação de efluentes, além das águas cinzas originadas de banheiros, chuveiros, e pias de cozinha, e águas pluviais entre os anos 2000 e 2020.

Palavras-chave: revisão sistemática; caracterização; águas residuárias; águas cinzas; águas pluviais 


\section{INTRODUCTION}

Fresh water consumption is increasing worldwide due to the acceleration of population growth, followed by urbanization and industrial development [1]. Such water resources, both underground and surface have been exploited incessantly throughout history, which has generated their pollutions, making them no longer usable by humans. This increase in water demand is linked to eventualities such as climate change and river pollution [1-3]. Agriculture, dams and changes in land use are also reshaping the rate, expansion and distribution of consumption and replenishment of fresh water [4].

One of the sustainable solutions in the management of water resources is the recycling of wastewater. The treatment of wastewater in the 20th century highlighted the theme of protecting public health, reducing pollution and preventing environmental degradation [4]. On the other hand, wastewater consumption can affect human health due to the presence of active chemicals and endocrine disruptors, micropollutants, including pharmaceuticals and personal care products, polycyclic aromatic hydrocarbons (PAHs), phosphorus flame retardants, plasticizers and pesticides, pathogens, soil quality due to accumulation of salinity and toxic metals, contamination of groundwater by salts and the quality of crops [2,5,6,7].

There are also alternative sources for non-potable supply, with emphasis on the use of rainwater and gray water. Gray waters can be defined as wastewater originating from bathrooms, showers, washbasins, washing machines and tanks and kitchen sinks [8].

Taking into account the origin and destination of these waters, their characterization is of fundamental importance. It is through analysis that one can be sure that the water distributed is reliable, if it is free of microorganisms or chemicals harmful to health and the environment.

Park et al. (2009) examined the effects of $\mathrm{y}$-ray treatment on wastewater toxicity at a rubber plant in Korea using Daphnia magna, a small planktonic crustacean that belongs to the Phyllopoda subclass. An inductively coupled plasma optical emission spectrometry (ICP OES) was used to analyze $\mathrm{Al}, \mathrm{Cd}, \mathrm{Cu}, \mathrm{Cr}, \mathrm{Fe}, \mathrm{Pb}$ and $\mathrm{Zn}$. With the results it was noticed that the gamma ray treatment did not completely remove the toxicity of wastewater and effluents from a rubber factory, suggesting that the main toxic agents were probably cationic metals [9].

Pang et al. (2016) used a sorting stir bar extraction (SBSE) with chemical derivatization to pre-concentrate 29 biogenic carbonyl compounds in rainwater samples in Yor, United Kingdom. For the detection and quantification of species gas chromatography coupled to mass spectrometry (GC-MS) was used. The sensitivity of the method using SBSE was evaluated in terms of LOD. The SBSE LODs of the 29 species studied ranged from 0.02 to $0.24 \mu \mathrm{g} / \mathrm{L}$. The LODs of the SBSE-GC-MS technique for carbonyl measurements employed in this work were lower than those of gas chromatography-electron capture detector (GC-ECD) and solid phase microextraction with detection by high performance liquid chromatography (SPME HPLC-UV) [10].

In this context, the following work aimed to carry out a systematic review on the main techniques used for the evaluation of metals and organic compounds in wastewater, graywater and rainwater, highlighting the magazines with the largest 
number of publications, the countries that most published on the subject, the years with the largest number of publications and the most applied techniques between the years 2000 and 2020.

\section{METHODOLOGY}

To find the techniques used for the evaluation of chemical compounds in different types of wastewater, gray water and rainwater, a systematic review was used in four databases: Science Direct (https://www.sciencedirect.com" https://www.sciencedirect.com), Web of Science (https://www.webofknowledge.com/" https://www.webofknowledge.com/), Scopus (https://www.scopus.com/home.uri" https://www.scopus.com/home.uri) and Scielo (https://www.scielo.org/" https://www.scielo.org/). To start the systematic review, search filters were selected using the keywords: wastewater; gray waters; rainwater; metals; organic compounds. The research period was from 2000 to 2020.

\section{RESULTS AND DISCUSSION}

The application of the systematic review resulted in 83 studies found according to the established filters. Table 2 shows the number of publications found for each investigated database. The works were found in 41 magazines, where the "Atmospheric Environment" stood out with the number of 7 articles published, followed by the " Revista Brasileira de Engenharia Agrícola e Ambiental " and "Water Research" with 6 articles published in each magazine.

Table 2. Number of publications found for each database

\begin{tabular}{|c|c|}
\hline Data base & Number of publications \\
\hline Science Direct & 20 \\
\hline Web of Science & 33 \\
\hline Scopus & 17 \\
\hline Scielo & 13 \\
\hline
\end{tabular}

Brazil was the country that most showed interest in the characterization of waters that can be recycled (wastewater, graywater and rainwater), presenting a total of 19 articles, followed by China with 8 published articles and the United States with 7 articles. Figure 2 shows the countries that published articles related to the researched topic followed by the number of publications.

The graph shown in Figure 3 shows that the publications of the articles were distributed over the years in an eventual way, not showing a sequential growth in the number of publications each year, but a growth followed by a decrease each year, with distinction of the period between the years 2008 and 2011, where 27 articles were published, $33.3 \%$ of the 83 articles published. 
Figure 2. Countries that published on the topic

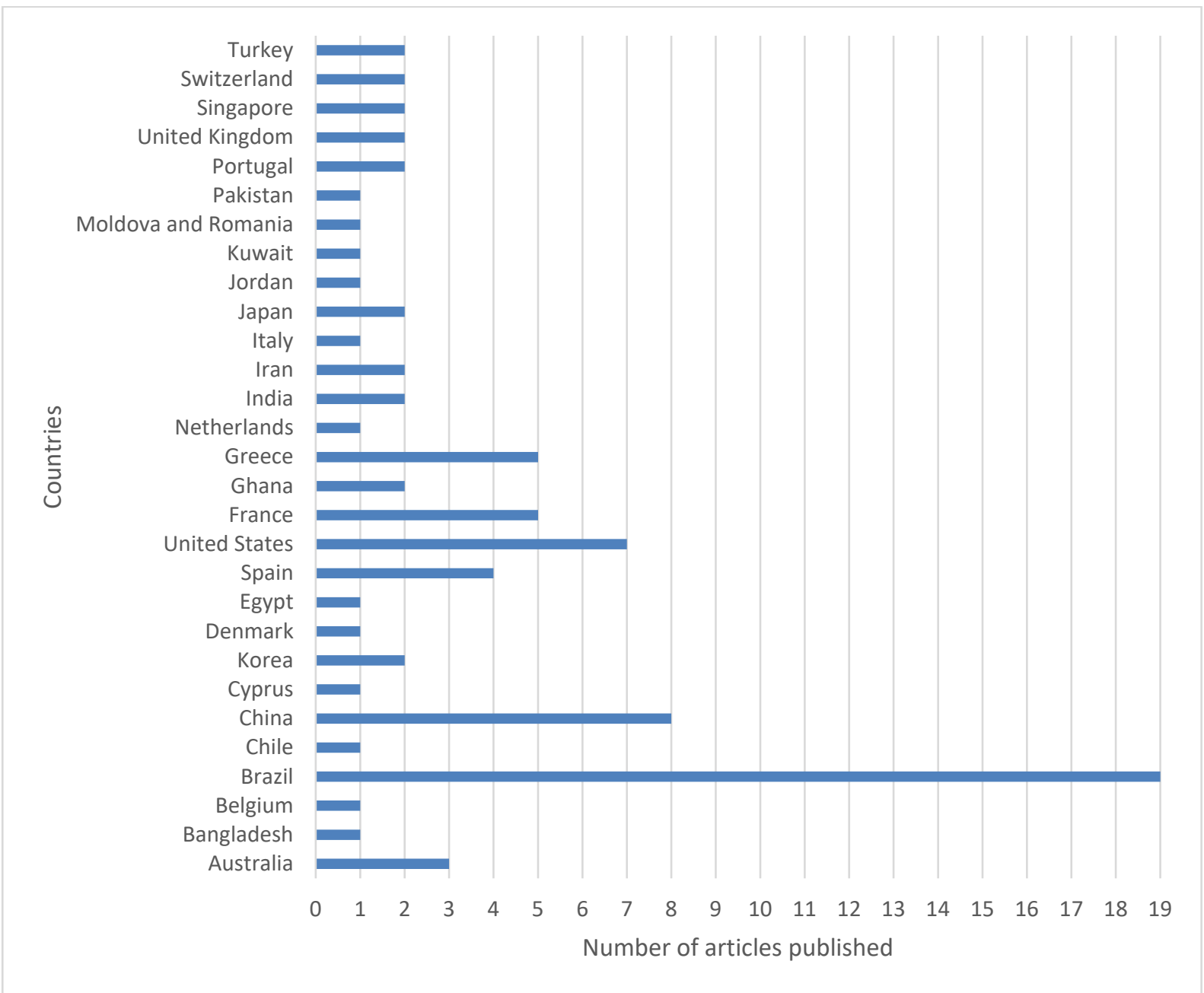

Figure 3. Number of articles published per year

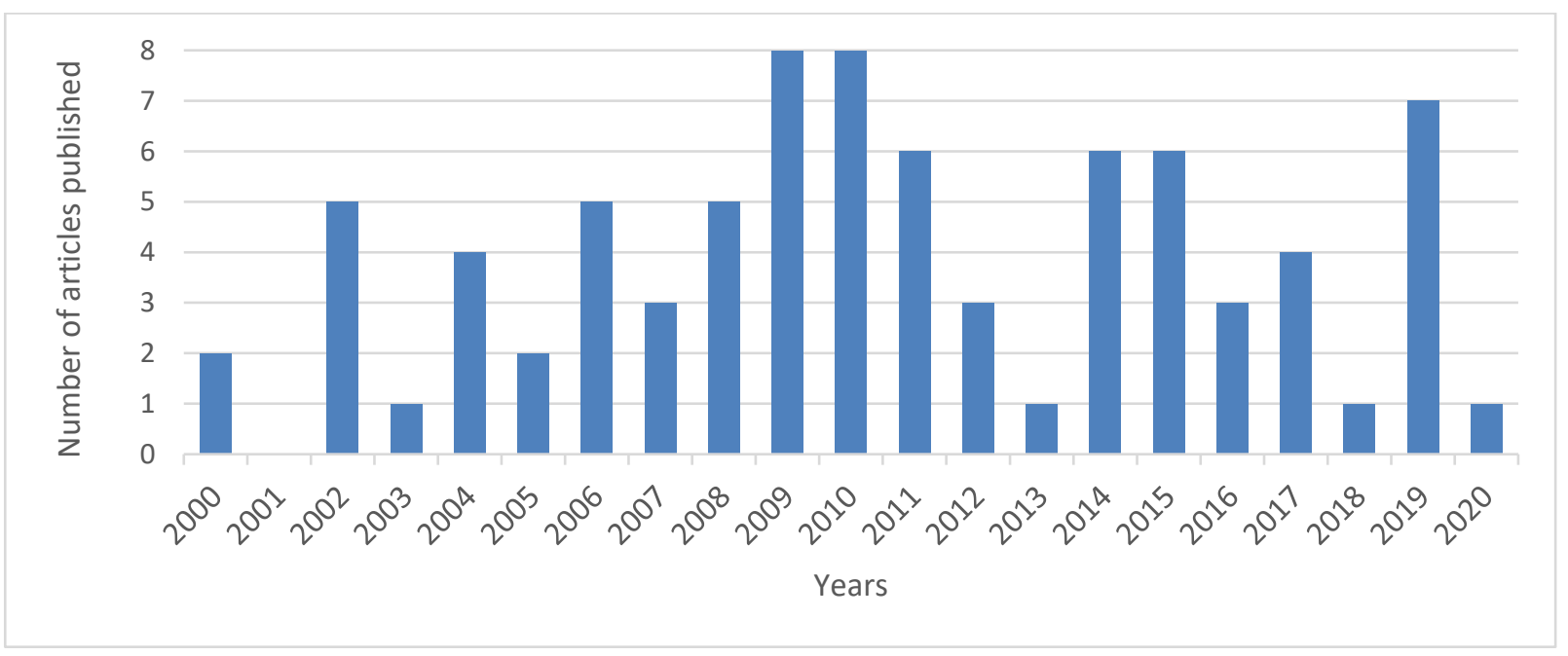


At least 18 techniques were used for the determination of metals in wastewater, graywater, and rainwater. The metals most found in the articles were $\mathrm{Cd}, \mathrm{Cu}, \mathrm{K}, \mathrm{Na}$ and $\mathrm{Pb}$. Inductively coupled plasma optical emission spectrometry (ICP OES) and inductively coupled plasma mass spectrometry (ICP-MS), totaled 15 applications for the evaluation of metals in the mentioned waters. Jambers and colleagues used both techniques, ICP OES (detection limits 0.2-3.0 ppb; accuracy 10\%) and ICP MS (detection limits 1-100 ppt; accuracy 10\%) for the inorganic characterization of water in the rain collected above the North Sea [11]. ICP based techniques have been highlighted for their versatility and detection capacity. Spectrometer meter plasma usually reaches a temperature of $8,000 \mathrm{~K}$ and a less reactive chemical environment than an atomizer flame. The high temperature determined by the plasma source allows a highly sensitive determination of common elements determined to be determined by other analytical techniques, such as refractory metals or that form refractory oxides , rare earth elements and light elements like boron [12].

Other techniques worth mentioning are atomic absorption spectrometry (AAS). Flame atomic absorption spectrometry (F AAS), graphite furnace atomic absorption spectrometry (GF AAS), hydride generation coupled to atomic absorption spectrometry (HG AAS), and cold vapor atomic absorption spectrometry (CV AAS); had a sum of 18 applications. AAS, also widely used, has been compared throughout history with ICP. Its advantages compared to ICP are: lower equipment and operational costs, ease of operation, and a reduced number of spectral lines, allowing less interference by overlapping lines. However, AAS has a small linear working range, less analytical frequency, and some non-metallic elements are not easily determined, such as phosphorus and sulfur, and mainly, it is considered a monoelementary analytical technique, its greatest disadvantage [13]. Buzier et al. (2006) used GF AAS to determine copper and cadmium in wastewater samples after using a diffusive gradient in the thin film technique (DGT) as a tool for metal speciation, concluding that DGT can be very useful to provide an operational fractionation of metals in wastewater [14].

Others were also used in the studies studied, such as flame photometry, in the determination of sodium in gray waters [15]; ion chromatography with conductometric detection, used by Fontenele and Pedrotti to determine copper, lead, cadmium, as well as major cations and anions in rainwater samples [16]; the differential pulse anodic stripping voltammetry (DPASV), used by C. Prestes and collaborators to determine copper, lead and cadmium in rainwater samples [17]; in addition to flow injection analysis (FIA) with anodic stripping voltammetry detection; competitive ligand exchange-adsorptive cathodic stripping voltammetry techniques (CLE-ACSV); atomic emission spectrophotometer with flame atomization; voltammetric determination by anodic stripping using a chitosan modified carbon paste electrode; colorimetry; titrometry; differential pulse cathodic stripping voltammetry (DPCSV); infrared spectroscopy; sequential injection analysis (SIA), X-ray fluorescence (XRF); and UV absorbance, totaling the use of 20 techniques used with different methodologies in 56 of the 83 articles found.

Gas chromatography coupled with mass spectrometry (GC-MS) has been the most used technique for the determination of organic compounds in wastewater, graywater, and rainwater, during the last 20 years [18]. GC-MS is applicable to volatile and thermally stable compounds at the relatively high temperatures employed during the chromatographic separation process. These requirements are similar to those required for compounds to be ionized by means of IE and IQ ${ }^{2}$ [19]. An analytical strategy involving the use of GC-MS certainly has the advantage of enabling 
identification with excellent sensitivity and reproducibility for compounds that occur in complex matrices [20]. Noutsopoulos et al. (2017) characterized gray water samples from Greek households using GC-MS according to Samaras et al. (2011) to assess micropollutants present in them [21].

Then, the technique with more appearances was high performance liquid chromatography (HPLC). HPLC uses small columns, filled by a mobile phase that is eluted under high pressures. This technique has the ability to perform separations and quantitative analyzes of a large number of compounds present in various types of samples, in a few minutes, with high resolution, efficiency and sensitivity. Due to its characteristics, it is widely used in the pharmaceutical industry [22]. Eschauzier et al. (2010) used HPLC to determine perfluorinated compounds in the infiltrated water of the Rhine and rainwater infiltrated in coastal dunes [23].

A wide variety of organic compounds was found in the studied waters, such as recalcitrant compounds, biogenic carbonyl compounds, perfluorinated compounds, aldehydes, phenolic compounds, hydroquinones, among others.

Other techniques appeared less frequently, such as cyclic voltammetry with vitreous carbon electrode modified with bismuth film, used by Santos et al. [24] to determine 2,4-dinitrophenol (2,4-DNP) in rainwater from regions of Santa Catarina; in addition to UV/visible spectroscopy; fluorescence spectrophotometry; thermo-optical analyzer; high temperature combustion (HTC); capillary electrophoresis; high temperature catalytic oxidation; cyclotron ion resonance mass spectrometry by ESI Fourier transformation (FT-ICR MS); liquid chromatography coupled to a photodiode matrix detector (HPLC-DAD) and sources of chemical ionization ions by atmospheric pressure (LC-APCl-MS); Bound liquid chromatography coupled to two mass spectrometers (LC-MS/S); and thermoionic flame detector (GC-FTD), totaling the sum of 13 techniques employed with different methodologies in 42 of the 83 articles found.

\section{CONCLUSION}

The use of the systematic review was able to identify a considerable amount of specific research articles from the last 20 years, making it possible to evaluate the databases, journals, countries, years of publication, and techniques used for the analysis of metals and organic compounds in wastewater, gray waters and rainwater, facilitating a possible choice and future implementation of techniques for the characterization of water samples. The characterization of these waters is of paramount importance to ensure their potability, verifying their quality from different sources, reaching the standards of demand for their use.

\section{Acknowledgments}

I am grateful to the Fundação de Amparo à Pesquisa do Estado Bahia (FAPESB) for the financial support given to the research project in which this work is inserted. 


\section{REFERENCES}

${ }^{1}$ SUN, Xiao et al. Organic acids in cloud water and rainwater at a mountain site in acid rain areas of South China. Environmental Science and Pollution Research, v. 23, n. 10, p. 9529-9539, 2016.

2 PEDRERO, Francisco et al. Use of treated municipal wastewater in irrigated agriculture-Review of some practices in Spain and Greece. Agricultural Water Management, v. 97, n. 9, p. 1233-1241, 2010.

$3 \mathrm{XU}$, Jianying et al. Bioassay: A useful tool for evaluating reclaimed water safety. Journal of Environmental Sciences, v. 88, p. 165-176, 2020.

${ }^{4}$ ASANO, T.; LEVINE, A. D. Recovering sustainable waste from wastewater. Environ Sci Technol, v. 38, p. 201A-208A, 2004.

${ }^{5}$ BIGGS, Trent W.; JIANG, BinBin. Soil salinity and exchangeable cations in a wastewater irrigated area, India. Journal of environmental quality, v. 38, n. 3, p. 887896, 2009.

6 CHEN, Weiping et al. Reclaimed water: A safe irrigation water source? Environmental Development, v. 8, p. 74-83, 2013.

7 WANG, Juan et al. Monitoring of 943 organic micropollutants in wastewater from municipal wastewater treatment plants with secondary and advanced treatment processes. Journal of Environmental Sciences, v. 67, p. 309-317, 2018.

8 MAY, Simone. Caracterização, tratamento e reúso de águas cinzas e aproveitamento de águas pluviais em edificações. 2009. Tese de Doutorado. Universidade de São Paulo.

${ }^{9}$ PARK, E. et al. Effects of gamma-ray treatment on wastewater toxicity from a rubber products factory. Journal of radioanalytical and nuclear chemistry, v. 277, n. 3, p. 619-624, 2008.

10 PANG, Xiaobing; LEWIS, Alastair C.; SHAW, Marvin D. Analysis of biogenic carbonyl compounds in rainwater by stir bar sorptive extraction technique with chemical derivatization and gas chromatography-mass spectrometry. Journal of separation science, v. 40, n. 3, p. 753-766, 2017.

11 JAMBERS, W.; DEKOV, V.; VAN GRIEKEN, R. Single particle and inorganic characterization of rainwater collected above the North Sea. Science of the total environment, v. 256, n. 2-3, p. 133-150, 2000.

12 NOVAES, Cleber Galvão et al. A review of multivariate designs applied to the optimization of methods based on inductively coupled plasma optical emission spectrometry (ICP OES). Microchemical journal, v. 128, p. 331-346, 2016.

13 AMORIM, Fábio Alan Carqueija et al. Espectrometria de absorção atômica: o caminho para determinações multi-elementares. Quim. Nova, p. 1784-1790, 2008.

14 BUZIER, Rémy; TUSSEAU-VUILLEMIN, Marie-Hélène; MOUCHEL, Jean-Marie. Evaluation of DGT as a metal speciation tool in wastewater. Science of the Total Environment, v. 358, n. 1-3, p. 277-285, 2006. 
15 OTENG-PEPRAH, M.; DE VRIES, N. K.; ACHEAMPONG, M. A. Greywater characterization and generation rates in a peri urban municipality of a developing country. Journal of environmental management, v. 206, p. 498-506, 2018.

16 FONTENELE, Anna Paula Godoy; PEDROTTI, Jairo J.; FORNARO, Adalgiza. Avaliação de metais traços e íons majoritários em águas de chuva na cidade de São Paulo. Química Nova, v. 32, n. 4, p. 839-844, 2009.

17 PRESTES, Ellen C. et al. Copper, lead and cadmium loads and behavior in urban stormwater runoff in Curitiba, Brazil. Journal of the Brazilian Chemical Society, v. 17, n. 1, p. 53-60, 2006.

18 NOUTSOPOULOS, C. et al. Greywater characterization and loadingsphysicochemical treatment to promote onsite reuse. Journal of environmental management, v. 216, p. 337-346, 2018.

${ }^{19}$ CHIARADIA, Mariza C.; COLLINS, Carol H.; JARDIM, Isabel CSF. O estado da arte da cromatografia associada à espectrometria de massas acoplada à espectrometria de massas na análise de compostos tóxicos em alimentos. Química nova, v. 31, n. 3, p. 623-636, 2008.

20 SALVATORE, Maria Michela et al. GC-MS approaches for the screening of metabolites produced by marine-derived Aspergillus. Marine Chemistry, v. 206, p. 1933, 2018.

21 SAMARAS, Vasilios $G$. et al. An analytical method for the simultaneous trace determination of acidic pharmaceuticals and phenolic endocrine disrupting chemicals in wastewater and sewage sludge by gas chromatography-mass spectrometry. Analytical and bioanalytical chemistry, v. 399, n. 7, p. 2549-2561, 2011.

22 SILVA, Patrícia Damasceno. Determinação de compostos fenólicos por HPLC. 2012. Tese de Doutorado.

${ }^{23}$ ESCHAUZIER, Christian et al. Perfluorinated compounds in infiltrated river rhine water and infiltrated rainwater in coastal dunes. Environmental science \& technology, v. 44, n. 19, p. 7450-7455, 2010.

24 SANTOS, Marcel Silveira dos; BIANCHIN, Joyce Nunes; SPINELLI, Almir. Desenvolvimento de metodologia analítica baseada em eletrodo de carbono vítreo modificado com filme de bismuto: Aplicação em águas de chuva de regiões de Santa Catarina. Eclética Química, v. 36, n. 2, p. 158-181, 2011. 